\title{
Potential of oak tree-ring chronologies from Southern Portugal for climate reconstructions
}

\author{
Sofia Leal ${ }^{\mathrm{a}, \mathrm{b}, c, *}$, Filipe Campelo $^{\mathrm{d}}$, Ana Luísa Luz ${ }^{\mathrm{c}}$, Maria Fátima Carneiro ${ }^{\mathrm{e}}$, \\ João Andrade Santos ${ }^{\mathrm{e}}$ \\ a iBET, Instituto de Biologia Experimental e Tecnológica, Av. República, Qta. do Marquês, 2780-157 Oeiras, Portugal \\ b ITQB, Instituto de Tecnologia Química e Biológica, Universidade Nova de Lisboa, Av. da República, 2780-157 Oeiras, Portugal \\ c CEF, Centro de Estudos Florestais, Instituto Superior de Agronomia, Universidade de Lisboa, Tapada da Ajuda, 1349-017 Lisboa, Portugal \\ d CFE, Centre for Functional Ecology, Department of Life Sciences, University of Coimbra, 3001-401 Coimbra, Portugal \\ e CITAB, Centre for the Research and Technology of Agro-Environmental and Biological Sciences, Universidade de Trás-os-Montes e Alto Douro, UTAD, \\ 5000-801 Vila Real, Portugal
}

\section{A R T I C L E I N F O}

\section{Article history:}

Received 11 March 2015

Received in revised form 13 May 2015

Accepted 13 May 2015

Available online 23 May 2015

\section{Keywords:}

Dendrochronology

Oak

Quercus spp.

Mediterranean

\begin{abstract}
A B S T R A C T
The present work reports a first attempt to assemble long tree-ring chronologies from Portugal potentially useful for climate reconstructions. Three oak species (Quercus pyrenaica, Quercus faginea, and Quercus ilex) were sampled at three sites in southern Portugal to obtain tree-ring chronologies. The longest tree ring series covers 173 years extending back to 1840 . Our tree-ring records show, depending on the site, moderate-to-high correlations with precipitation in different seasons (from $r=0.40, p<0.01$, to 0.81 , $p<0.001$ ) and temporal stability in the growth/climate relationship for two sites. Calibration-verification trials confirm the reliability of climate/growth models for climatic reconstructions back to periods represented by tree-ring records from these two sites. Regional precipitation for Alentejo can be estimated for the following seasons: April through August (calibration $r^{2}=0.24$ ); September, from previous year, to July (calibration $r^{2}=0.65$ ). The results are a promising kick-off for Portuguese dendroclimatology, since they represent a significant breakthrough in the Mediterranean region, especially for Iberian Peninsula, where there is a considerable lack of dendroclimatic reconstructions. Further efforts to extend the tree-ring records back in time using subfossil material should be undertaken.
\end{abstract}

(c) 2015 Elsevier GmbH. All rights reserved.

\section{Introduction}

The potential threats resulting from a changing climate have highlighted the importance of paleoclimatology studies in improving the current understanding of the climate system. The Earth's climate is progressively becoming warmer and this trend is projected to further enhance in future decades under anthropogenic forcing (IPCC, 2014a,b). The Mediterranean region is a climate change hotspot, as significant warming and drying are expected (Giorgi, 2006; Beniston et al., 2007; Gao and Giorgi, 2008; Nikulin et al., 2011; Diffenbaugh and Giorgi, 2012). Indeed, this region is at risk of experiencing the strongest alterations in ecosystem structure and composition, since it is already under vulnerable conditions (Cotillas et al., 2009; Sanchez-Salguero et al., 2010; Liñares

* Corresponding author at: iBET, Av. República, Qta. do Marquês, 2780-157 Oeiras, Portugal. Tel.: +351 214469636; fax: +351214 421161 .

E-mail address: spleal@yahoo.co.uk(S. Leal). and Tiscar, 2011; Pasho et al., 2011; Candel-Perez et al., 2012). Therefore, improving the current knowledge on past climate variability in Mediterranean climates is a top priority.

However, long and high quality dendroclimatic reconstructions for Mediterranean areas are scarce (Nicault et al., 2008). This is due to the extreme difficulties to obtain long tree-ring chronologies with strong and consistent climatic signals in Mediterranean-like climates, particularly when compared to central European climates (as reviewed by Cherubini et al., 2003). Efforts to overcome this drawback have increased considerably in the very recent years. Multicentennial-long tree-ring chronologies have been used to study temperature in the Pyrenees (Büntgen et al., 2010; DoradoLiñán et al., 2012a), event years in central Spain (Genova, 2012), water-use efficiency in eastern Spain (Andreu-Hayles et al., 2011), drought variability in northwestern Africa (Esper et al., 2007; Touchan et al., 2011), Greece (Sarris et al., 2011) and in the Mediterranean Basin (Touchan et al., 2005; Nicault et al., 2008), as well as the North Atlantic Oscillation (NAO) index (Trouet et al., 2009). Although Touchan et al. (2011) used 48 oak trees from three sites 
(out of a total of 837 trees and 39 sites) most of the aforementioned studies used conifer species.

In the South of Portugal, southwestern Iberia, tree-rings of pine species have shown a good agreement with climatic variables (e.g. Pinus pinea, Campelo et al., 2007b, Pinus pinaster, Campelo et al., 2013; Vieira et al., 2010), but the oldest pines in this area are younger than 150 years. Oaks are potentially the oldest trees in mainland Portugal. Drought-resistant evergreen Mediterranean oak species (e.g. Quercus ilex and Quercus suber) are widely distributed in the south. Moving northwards, they are gradually replaced by marcescent sub-Mediterranean species (e.g. Quercus faginea and Quercus pyrenaica), and then by deciduous temperate species (e.g. Quercus petraea and Quercus robur), already in the Atlantic biogeographical zone (Benito-Garzon et al., 2008).

The longest tree-ring series for Portugal are ca. 250 year-old, from $Q$. robur growing in sub-humid microclimates in Central Portugal, but showing very low synchrony between samples (Santos et al., 2015). Nevertheless, low-frequency variability in some of these tree ring series is in agreement with long-term trends in spring precipitation. The remaining studies with oak species have mostly analyzed short tree-ring series ( $<100$ years). The climate/growth relationships are remarkably strong in young trees (<30 yrs) of $Q$. suber (Leal et al., 2008), and Q. ilex (Campelo et al., 2007a, 2010) and in old trees (> 100yrs) of Q. ilex (Campelo et al., 2009, Abrantes et al., 2013), even higher than those for temperate regions. However, these results were only possible to achieve by using stem cross sections resulting from authorized tree fellings. There are very strict regulations in the country concerning tree felling for these two species, particularly for Q. suber, which is a highly protected species because of its cork production. The transitional species, between Mediterranean and mesic oaks, such as Q. pyrenaica (Corcuera et al., 2002) and Q. faginea (Corcuera et al., 2004), because of their ring-porous wood and distinct rings, can be sampled through tree coring. This greatly improves the whole process of tree-ring chronology development, while still providing valuable climatic signals. Some studies successfully used cores from Q. pyrenaica to explore climatic control over this species growth in Iberia (Corcuera et al., 2006; Roig et al., 2009; Rozas et al., 2009; Gea-Izquierdo and Cañellas, 2014; González-González et al., 2014). To our knowledge, climate/growth relationships in $Q$. faginea were rarely studied using cores (e.g. Granda et al., 2014), despite its tree rings showing a response to climatic variables (Corcuera et al., 2004).

The present study is a first attempt to establish long treering chronologies for dendroclimatic reconstructions in mainland Portugal. For that purpose, three oak species $(Q$. pyrenaica, $Q$. faginea, and $Q$. ilex) were sampled at three sites in southern Portugal. For each species: (a) the limitations in identifying and measuring tree rings; (b) the quality of the obtained chronologies, based on the strength of their common signal; and (c) their ability for dendroclimatic reconstructions, based on the strength and temporal stability of the climatic signals, are analyzed.

\section{Material and methods}

Tree-ring patterns in long-lived oaks, growing in Portugal, southwestern Iberia, and their suitability for dendroclimatic reconstructions are analyzed herein. The sampling took place at three sites in southern Portugal (Fig. 1), which are characterized by Mediterranean climates - types Csa (inland sites) and Csb (coastal site), according to the Köppen-Geiger classification, updated for the period 1950-2000 (Kottek et al., 2006).

At least 10 trees per site were sampled from three oak species making a total of 39 trees used for further analysis (Table 1). Tree ring samples were obtained as whole stem discs in the

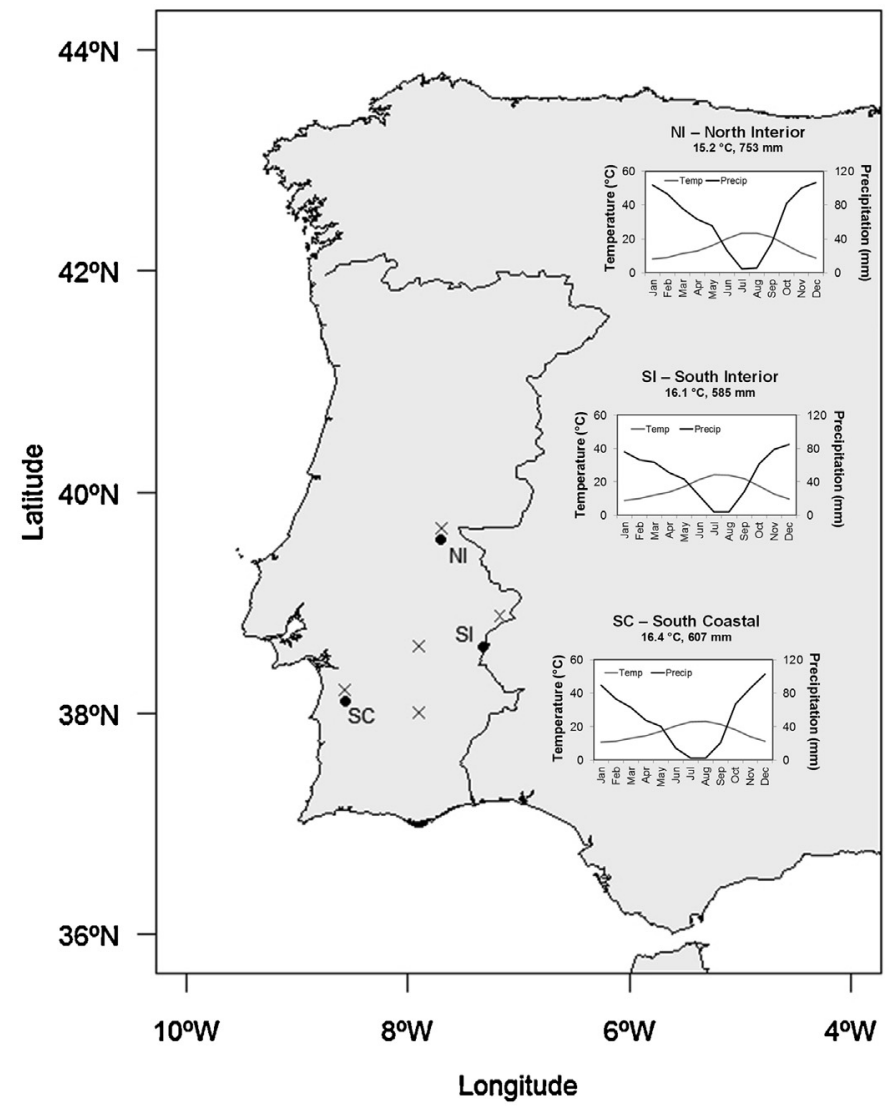

Fig. 1. Location of the study sites (NI: North Interior, SC: South Coastal, SI: South Interior), and respective ombrothermic diagrams for the closest meteorological stations (data from 1950 to 2000). The location of the meteorological stations used for the analysis of climate/growth relationships is also outlined $(x)$.

case of Q. ilex as described by Campelo et al. (2009), or through tree coring (two cores per tree) in the case of $Q$. pyrenaica and Q. faginea. After standard sample surface preparation, tree-ring widths (and also latewood widths in the case of ring porous species, $Q$. pyrenaica and $Q$. faginea) were measured to the nearest $0.001 \mathrm{~mm}$, using an increment measurement table, LINTAB Linear Table $560 / 2.5 \mathrm{~mm}$, connected to a stereo microscope LEICA M80 and the software TSAP-Win Scientific. Tree rings were crossdated within and between trees by visual inspection of single curves plots. The results were checked and supported using correlation coefficients, Gleichläufigkeit values (Fritts, 1976), and Student's $t$-test across tree ring series. Using ARSTAN software (Cook and Holmes, 1986), cubic smoothing splines, with a 50\% cut-off at a 60-year wavelength, were adjusted to the correctly dated series. Indexed series were obtained by dividing the original data through these curves. The effect of autocorrelation was removed and the resulting indexed series were averaged for each site using a bi-weight robust mean. The quality of the chronologies, concerning their strength of common signal and representativeness, was assessed through standard statistical indicators (Fritts, 1976; Wigley et al., 1984; Schweingruber et al., 1988; Cook and Kairiukstis, 1990): effective chronology signal $\left(r_{\text {eff }}\right)$ and expressed population signal (EPS), using the $\mathrm{R}$ package detrendeR (Campelo et al., 2012).

Climate/growth relationships were analyzed with Pearson correlations between each site chronology and climatic variables (monthly precipitation and temperature averages from previous year September to current December). Data from the closest meteorological stations were used (Fig. 1): São Mamede for NI, and 

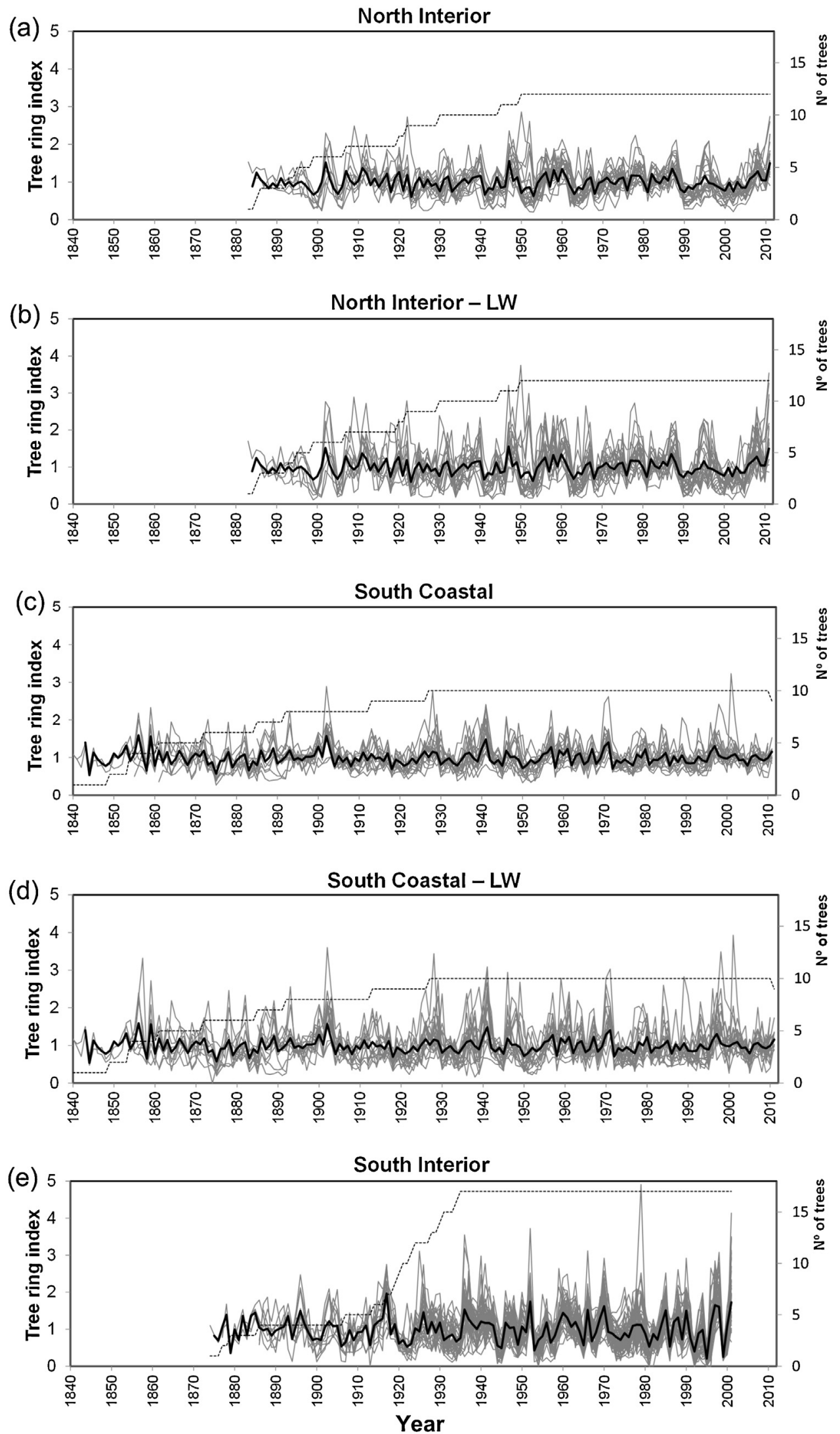

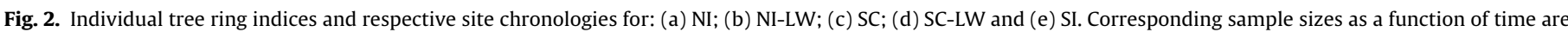
also shown (dotted line). 
(a)

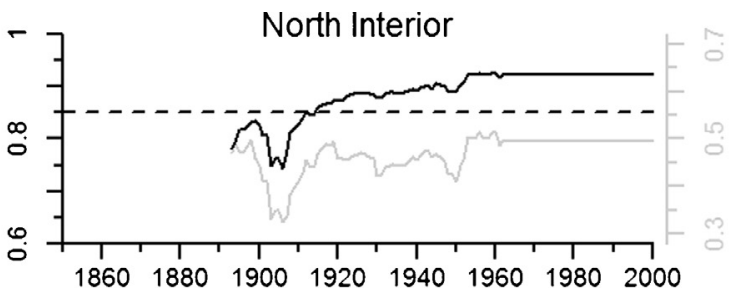

(b)

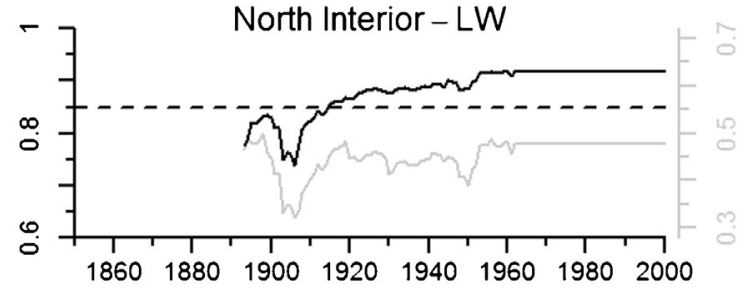

(c)

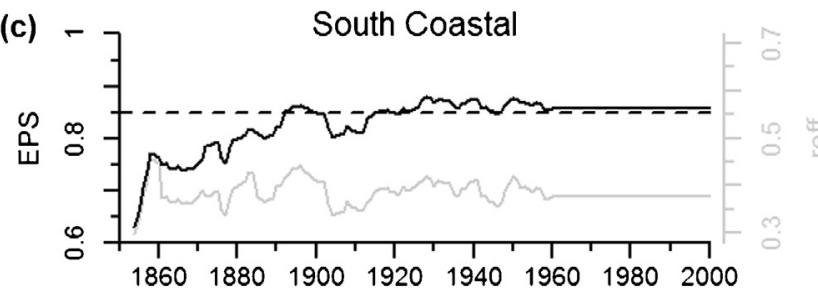

(d)

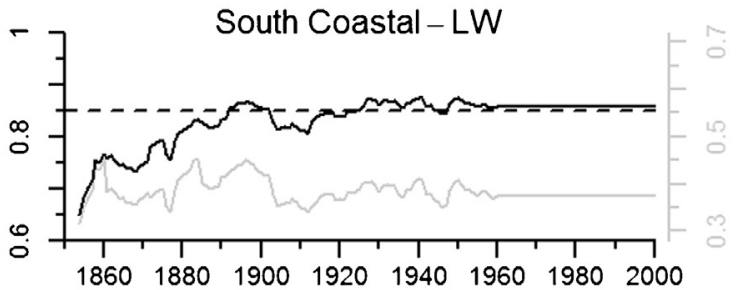

(e)

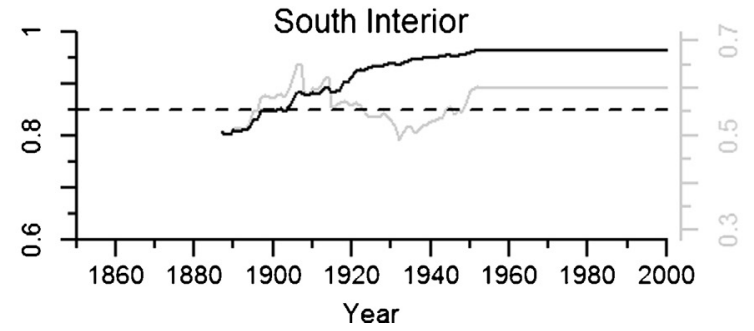

Fig. 3. Chronology statistics (EPS: Expressed Population Signal, in black; and $r_{\text {eff }}$ : Effective Chronology Signal, in gray) calculated from 50-year running periods lagged by 1 year for: (a) NI; (b) NI-LW; (c) SC; (d) SC-LW and (e) SI. Dashed line highlights EPS values above the 0.85 level (Wigley et al., 1984). The results are truncated to a sample size $>3$

Alentejo (average of four stations: Elvas, Beja, Évora, and Grândola) for SC and SI.

Since the available climatic data from the meteorological stations cover only the period from 1950 onwards, an appropriate verification of the temporal stability of the climatic signal is not possible. Therefore a long precipitation series for Lisbon - HistPT (Camuffo et al., 2013), showing a good agreement with the meteorological stations for total annual precipitation $(r=0.75, p<0.001$, for São Mamede; and $r=0.92, p<0.001$, for Alentejo), was used. The temporal stability of the climate/growth relationships was tested using 50-year moving windows, at 1-year lags, to calculate correlation coefficients between climatic and tree-ring records. Additionally, the period covered by tree-ring and climatic records was split in two for calibration-verification tests. Each sub-period was considered as an independent dataset and used to set up calibration models (regression equations between climate and growth records), which were verified/validated on the remaining one (Cook and Kairiukstis, 1990). The following statistical indicators were calculated to determine the model's skill to estimate climate variability on independent periods: $r^{2}$ for the calibration period; correlation coefficients between observed and estimated climatic data, using calibration equations on the verification period; reduction of error - RE (Blasing et al., 1981).

\section{Results}

For the ring porous species ( $Q$. pyrenaica and $Q$. faginea), two cores per tree were sufficient to crossdate within-tree, as ringwidth measurements showed very high agreement within trees $(r=0.70-0.73, p<0.001)$ and few missing rings. Despite having almost unmistakable tree-ring boundaries, crossdating between trees was extremely difficult and time consuming. In fact, cores from different trees depict highly variable, often non coincident, ring patterns. Nearly one third of the original samples were rejected due to poor crossdating with the remaining set. As tree ring boundaries are very difficult to recognize in $Q$. ilex, they were identified by the marginal parenchyma bands and by differences in vessel lumen area along the growth ring (for details see Campelo et al., 2009; Gea-Izquierdo et al., 2009). Stem cross-sections must be used for a proper tree ring dating, owing to diffuse porosity, highly variable ring width along the tree perimeter, and missing, interrupted and locally absent tree rings. In order to identify correctly missing rings, more than three radial directions in each disk were considered. A total of 41 missing rings were identified and all the samples were kept for further analysis.

The crossdated tree-ring series extended 173 years back in time (from 1840 to 2012), with average site segment lengths varying between 89 and 141 years (Table 2). The detrended individual treering series (based on ring width and, in the case of $Q$. pyrenaica and Q. faginea, latewood width measurements - LW) for each site, as well as the corresponding chronology (Fig. 2), revealed an effective chronology signal increasing southwards and inland $\left(r_{\text {eff }}=0.42\right.$ at $\mathrm{SC}$ and NI, $r_{\mathrm{eff}}=0.60$ at SI) (Table 2). EPS values are stable during the last section of the chronologies, decreasing only during the early less replicated period ( $<8$ trees), but for the period 1920-2000 all chronologies showed EPS values $>0.85$ (Fig. 3). This common variance observed for all chronologies evidences a good agreement in growth between trees at each study location.

The strongest climate/growth correlations (Fig. 4) were found between: NI and precipitation accumulated in winter (previous year December and current year January) before the start of the growing season $(r=0.40, p<0.01)$; SC-LW and spring-summer (April through July) precipitation $(r=0.50, p<0.001)$; SI and precipitation accumulated during autumn and winter, before the growth season onset, throughout spring and summer (previous year September through July of current year) $(r=0.81, p<0.001)$.

The correlations between each chronology and the normalized temporal series of the respective key climatic variable, calculated from a long precipitation dataset for Lisbon - HistPT (Camuffo et al., 2013), were lower than those obtained using the meteorological stations closer to the sampling sites (Fig. 5) - NI: $r=0.23$ (n.s.) vs $r=0.40(p<0.01)$; SC-LW: $r=0.46(p<0.01)$ vs $r=0.50(p<0.001)$; SI: $r=0.72(p<0.001)$ vs $r=0.81(p<0.001)$.

Temporal stability on the climate/growth relationships was analyzed using the HistPT series (Fig. 6). The northernmost site, NI, exhibits a very unstable relationship, with correlation coefficients rarely above the $95 \%$ significance level. SC-LW shows a relatively constant relationship along the period covered by the chronology (1840-2011), even at the lowest sample depth (number of trees $=1$ ), always above the $95 \%$ significance level. The exception was for 1900-1920, with lower but still statistically significant 
(a)

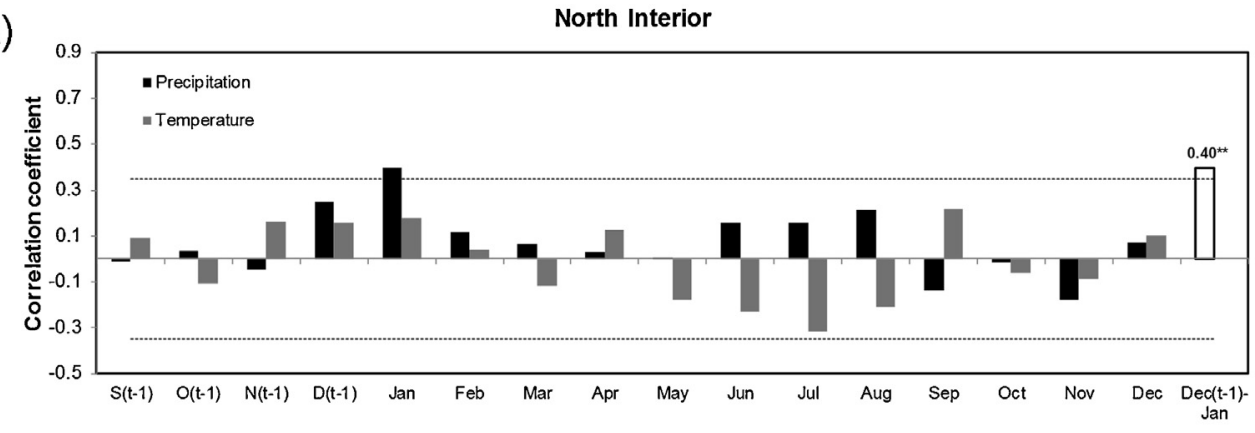

(b)

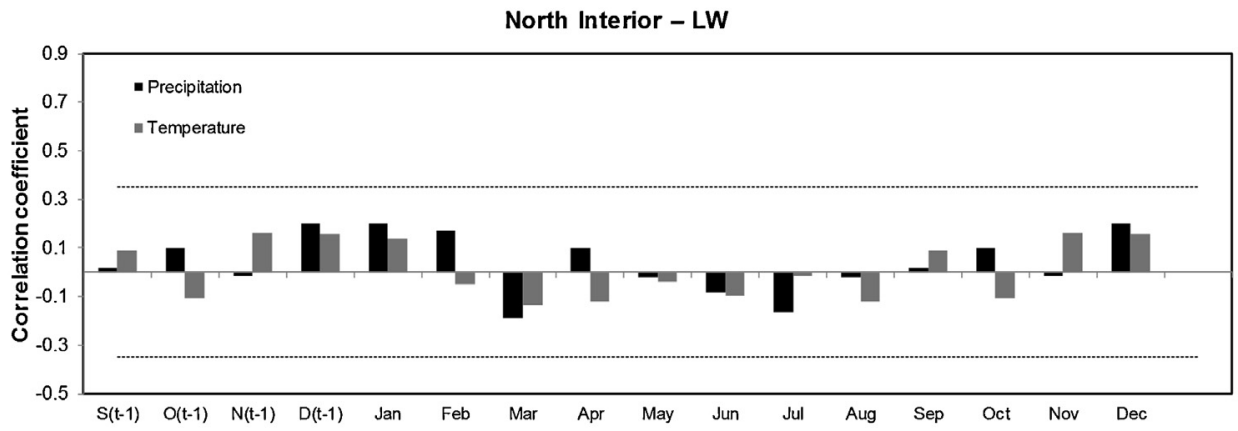

(c)

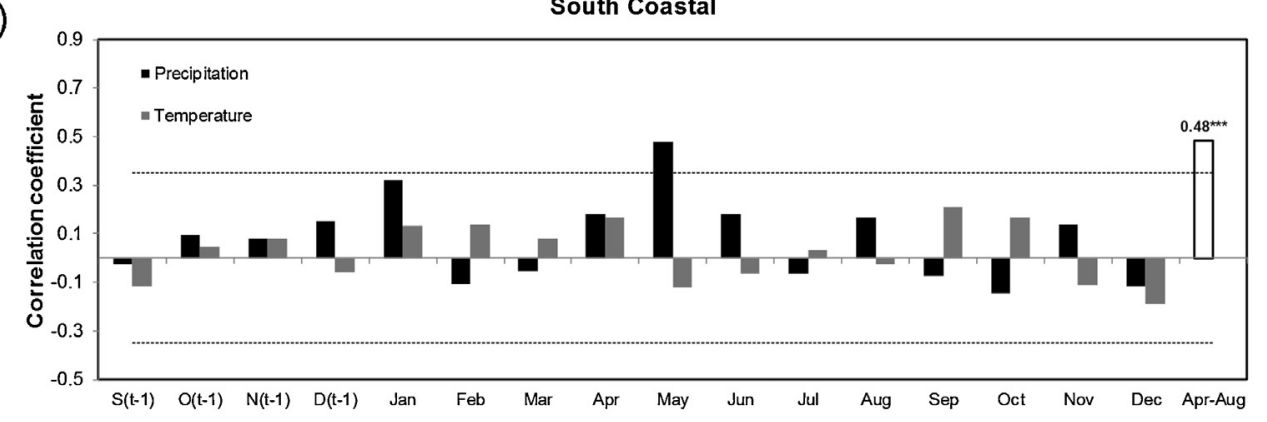

(d)

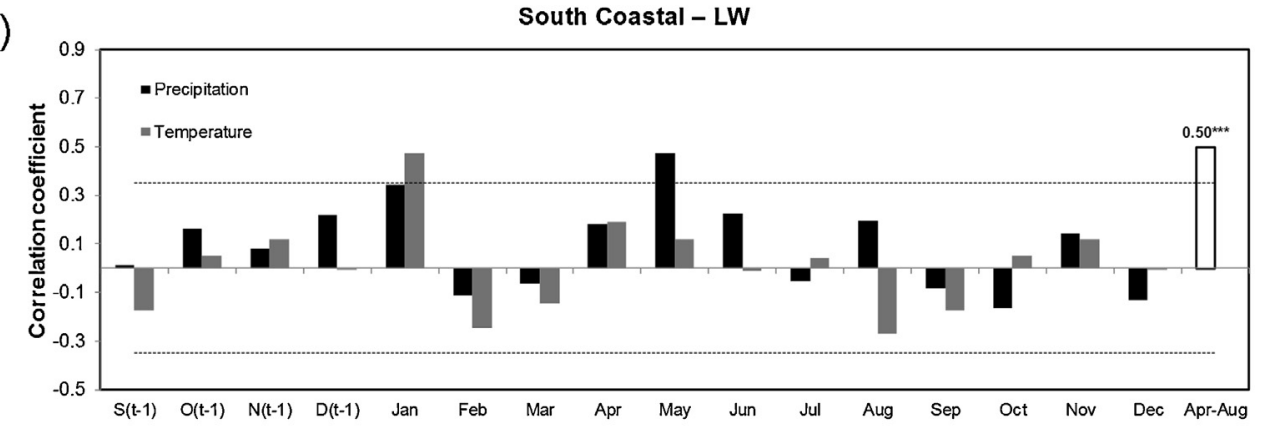

(e)

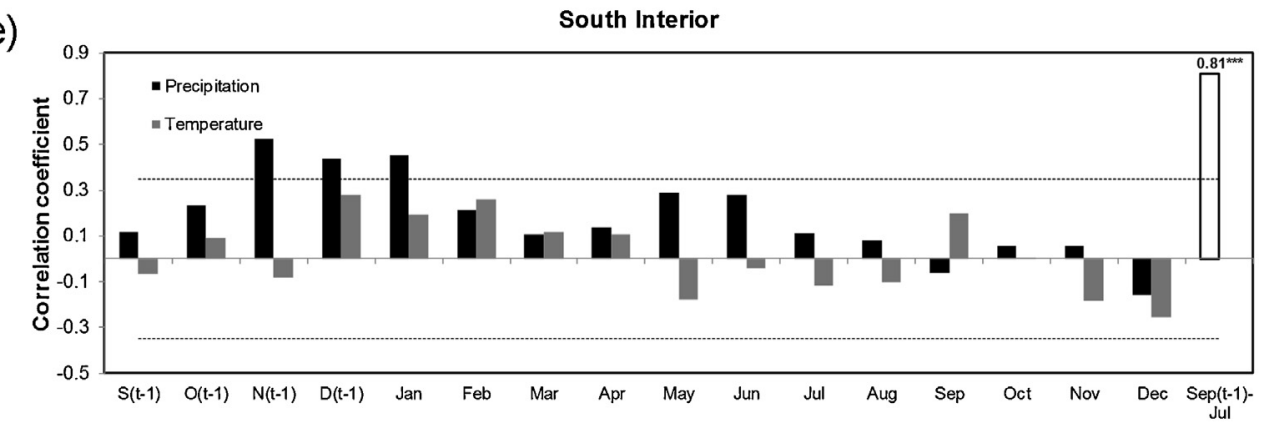

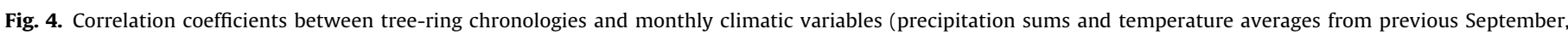

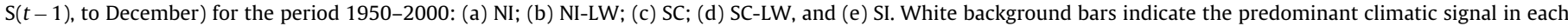
chronology $\left({ }^{* *} p<0.01,{ }^{* * *} p<0.001\right)$. Dashed lines represent the $99 \%$ confidence limit. 
(a)

North Interior

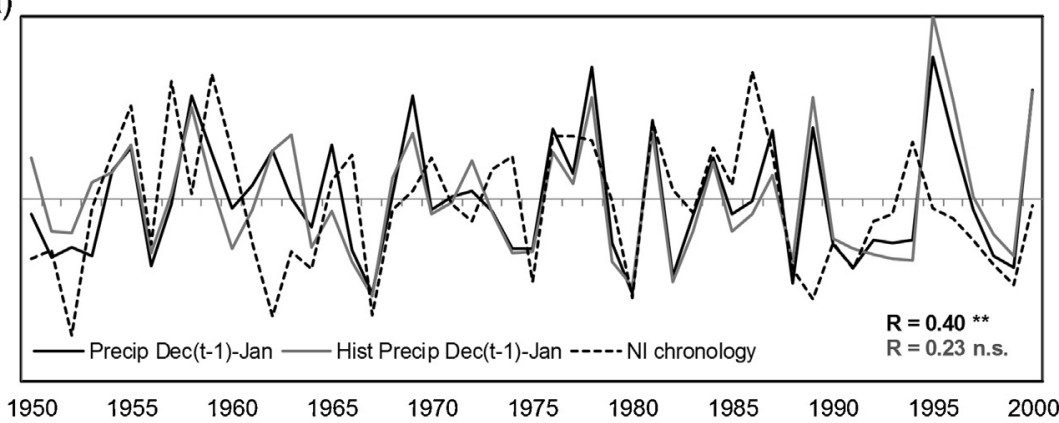

South Coastal - LW

(b)

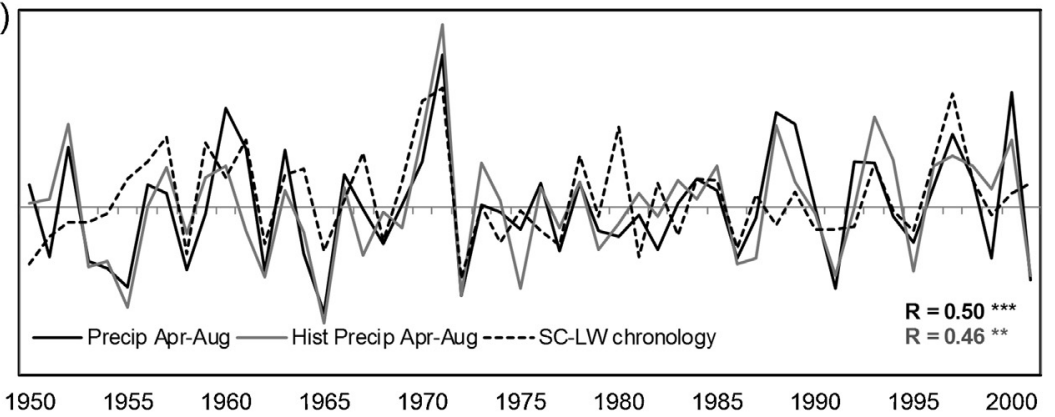

(c)

South Interior

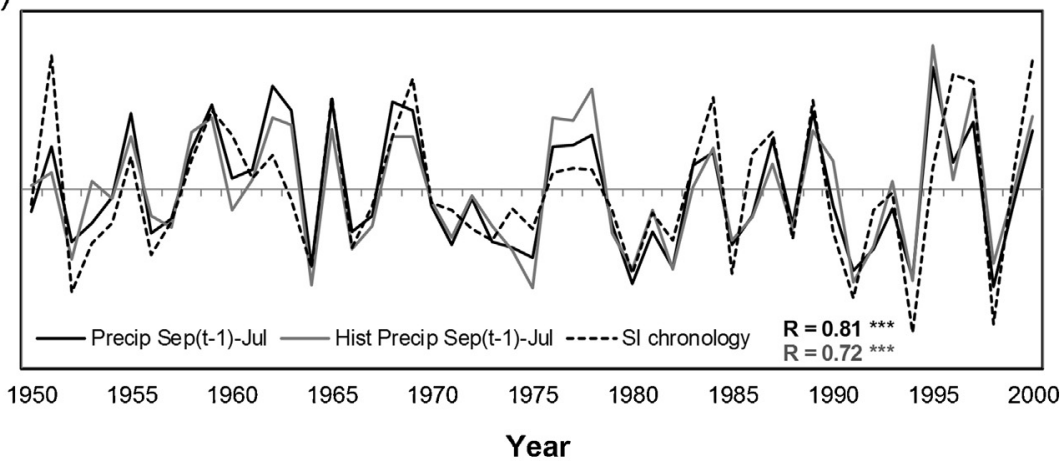

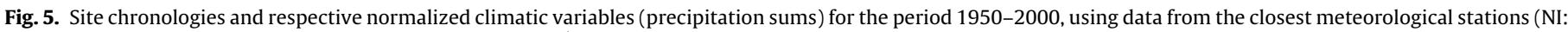

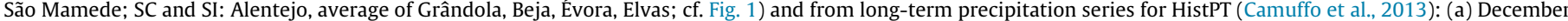

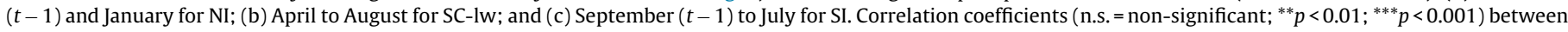
tree ring records and climatic data are shown in black (with closest stations) and in gray (with HistPT).

correlation coefficients. This period corresponds to a discontinuity in the chronology's reliability (Fig. 3d). Until 1892, at a sample depth of 8 trees, EPS is $>0.85$ excluding $1900-1920$ when it falls under 0.85 . At the SI site the correlations gradually drop, with the decrease in sample depth, from $0.73(p<0.001)$ to insignificant values (Fig. 6c).

The periods covered by tree-ring records showing the most stable climate/growth relationships, SC-LW and SI, were split into sub-periods for calibration-verification trials against HistPT data: 1899-1949, and 1950-2000 (Fig. 7).

\section{Discussion}

\subsection{From site and species selection to tree-ring crossdating}

An active survey for long lived oak tree species has been maintained. However, old trees that fulfill the principles of dendrochronology requirements (Fritts, 1976), namely growing healthy and undisturbed, in sufficient number for adequate replication, at sites where climate is potentially growth limiting, are difficult to locate in Portugal and sampling permission is not easy to obtain. Most of the present forest in mainland Portugal is relatively recent. Oak forests, which in Medieval times occupied most of the territory (Azevedo, 1997), have been gradually replaced by exotic species (such as $P$. pinaster and Eucalyptus globulus) with higher economic value. Evergreen species, Q. suber and Q. ilex, are nowadays still responsible for one third of the total mainland forested area, while the remaining oak species subsist in isolated and neglected stands, representing only $2 \%$ of the total forest area (ICNF, 2013). Therefore, proper site selection and experimental design are difficult to achieve as noted by Gea-Izquierdo et al. (2011). Nevertheless, climatic sensitive tree-ring records were obtained, the longest tree ring series extending back to 1840 , from Mediterranean and sub-Mediterranean oak species at three different sites, following a gradient from mesic to xeric conditions (Figs. 1 and 4).

The strength of the common signal between indexed treering series, measured by the effective chronology signal, $r_{\text {eff }}$, 
Table 1

Sites and trees description.

\begin{tabular}{|c|c|c|c|c|c|c|}
\hline Site code & Species & Soil & Altitude & Slope & Exposure & $\mathrm{N}$ trees \\
\hline $\mathrm{NI}$ & Q. pyrenaica & Prominent relief with quartzite outcrops; schists & $670 \mathrm{~m}$ & $5 \%$ & $\mathrm{~S}$ & 12 \\
\hline SC & Q. faginea & Paleiozoic schist and greywacke; shallow and poor & $150 \mathrm{~m}$ & - & - & 10 \\
\hline SI & Q. ilex & Schists; lithosols, shallow and poor & $135-145 \mathrm{~m}$ & $5 \%$ & - & 17 \\
\hline
\end{tabular}

(a)

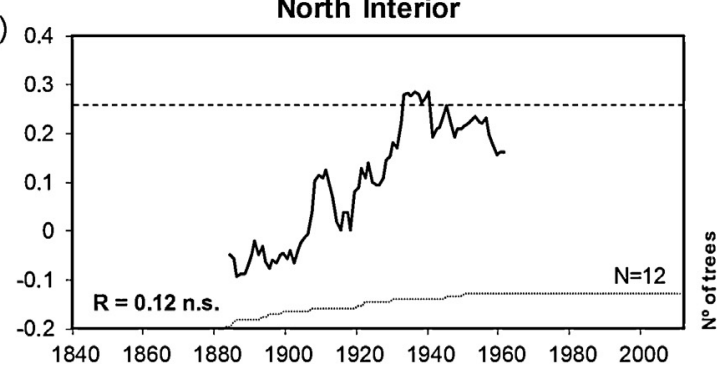

(b) 0.8
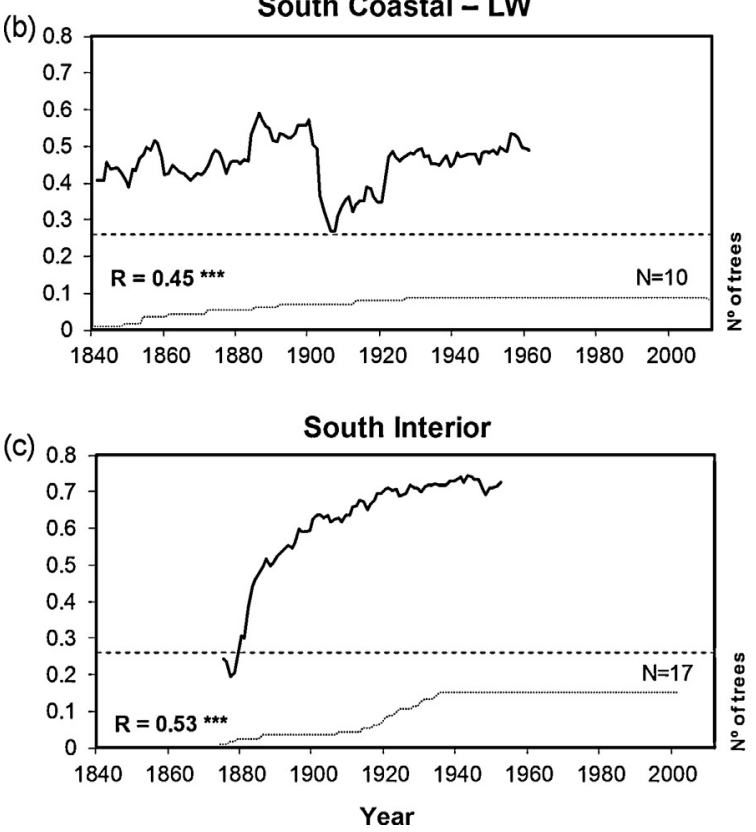

Fig. 6. Temporal stability on the climate/growth relationships given by 50 -years running correlation coefficients lagged by 1 -year between the site chronologies and the respective climatic variables (precipitation sums) using climatic records from HistPT: (a) December $(t-1)$ and January for NI; (b) April to August for SC-LW; and (c) September $(t-1)$ to July for SI. Correlation coefficients for the total period covered by the tree ring records are shown (n.s. = non-significant; ${ }^{* *} p<0.01 ;{ }^{* * *} p<0.001$ ). Dashed lines represent the $95 \%$ confidence limit and dotted lines the sample size as a function of time.

increases from mesic $\left(r_{\text {eff }}=0.42\right)$ to xeric $\left(r_{\text {eff }}=0.60\right)$ sites. The higher strength of association between different trees at SI is likely due to a higher number of trees but also to the more limiting site conditions. $Q$. ilex trees were growing under harsher conditions than the other two species, considering water availability, evidenced by a large number of missing rings. For the sites NI and NC more factors and interactions must have been at play.

\subsection{Tree-ring chronologies and climate/growth relationships}

The longest tree-ring series extends back to 1840 and the chronologies are representative after 1920 for the three sites $(E P S>0.85)$. All sites show a significant dominant climatic factor controlling growth (Fig. 4). The use of latewood width data improved the signal strength in the case of SC (SC-LW) but not for NI trees. Precipitation is the climatic parameter showing the strongest influence on tree-ring growth, despite some discrepancies between sites and species. Drought has been extensively pointed out as the main growth limiting factor for trees in the Mediterranean (reviewed by Pasho et al., 2011). At the more mesic sites, NI $(r=0.40, p<0.01$ with December $(t-1)$ to January precipitation) and SC-LW ( $r=0.50, p<0.001$ with April through July precipitation), the climatic signal strength is weaker. Since tree growth in the Mediterranean is controlled by multiple climatic factors, tree rings usually show weak-to-moderate climatic signals, generally much weaker than in temperate climates, and often not concentrated in a single season and/or varying from year to year (Olano et al., 2012). The climatic control is more pronounced and extending throughout a longer period of the year (September $(t-1)$ to July) at the most arid site, SI. The climate/growth relationship at this site is unusually high $(r=0.81, p<0.001)$, given that even for temperate climate where trees tend to show the highest climatic signals, tree ring records rarely explain more than $60 \%$ of the variability in the respective climatic factor (Hughes, 2002).

\subsection{Dendroclimatic reconstructions}

Many recent dendroclimatic studies report a diverging trend in the climate/growth relationship starting after the late 20th century (e.g. Briffa et al., 1998; Barber et al., 2000; Wilmking et al., 2004; Wilson and Elling, 2004; Büntgen et al., 2006; Carrer and Urbinati, 2006; D’Arrigo et al., 2008; Leal et al., 2008). The reasons for this change, or lack of climatic response, are not yet fully understood. Anyhow, this has raised great concern regarding the accuracy of dendroclimatic reconstructions, as they may be over- or underestimating past variability in climatic factors. Contrary to the aforementioned studies, climate/growth relationship is stable throughout the study period for SC-LW and SI (Fig. 6) similarly to $P$. nigra chronologies from southern Spain (DoradoLiñán et al., 2012b) and to a recent study from Alaska (Wiles et al., 2014). Calibration and verification statistics are robust (Fig. 7), assuring that growth/climate models remain skillful when applied to independent tree-ring data sets. Therefore, a high potential for dendroclimatic reconstructions is shown for SC-LW and SI chronologies. Although the present tree ring records do not

Table 2

Characterization of the tree ring series and basic statistics for tree-ring chronologies (RW = ring width; LW = latewood width).

\begin{tabular}{llll}
\hline Site code & NI & SC & SI \\
\hline First year & 1883 & 1840 & 1875 \\
Last year & 2012 & 2012 & 2002 \\
Average segment length & 99 & 141 & 89 \\
\multicolumn{1}{l}{ Statistical indicators of common signal strength $(1950-2000)$} & \\
EPS - expressed population signal & & \\
RW & 0.90 & 0.88 & 0.96 \\
LW & 0.89 & 0.87 & - \\
reff - effective chronology signal & & & \\
RW & 0.42 & 0.42 & 0.60 \\
LW & 0.40 & 0.40 & - \\
\hline
\end{tabular}



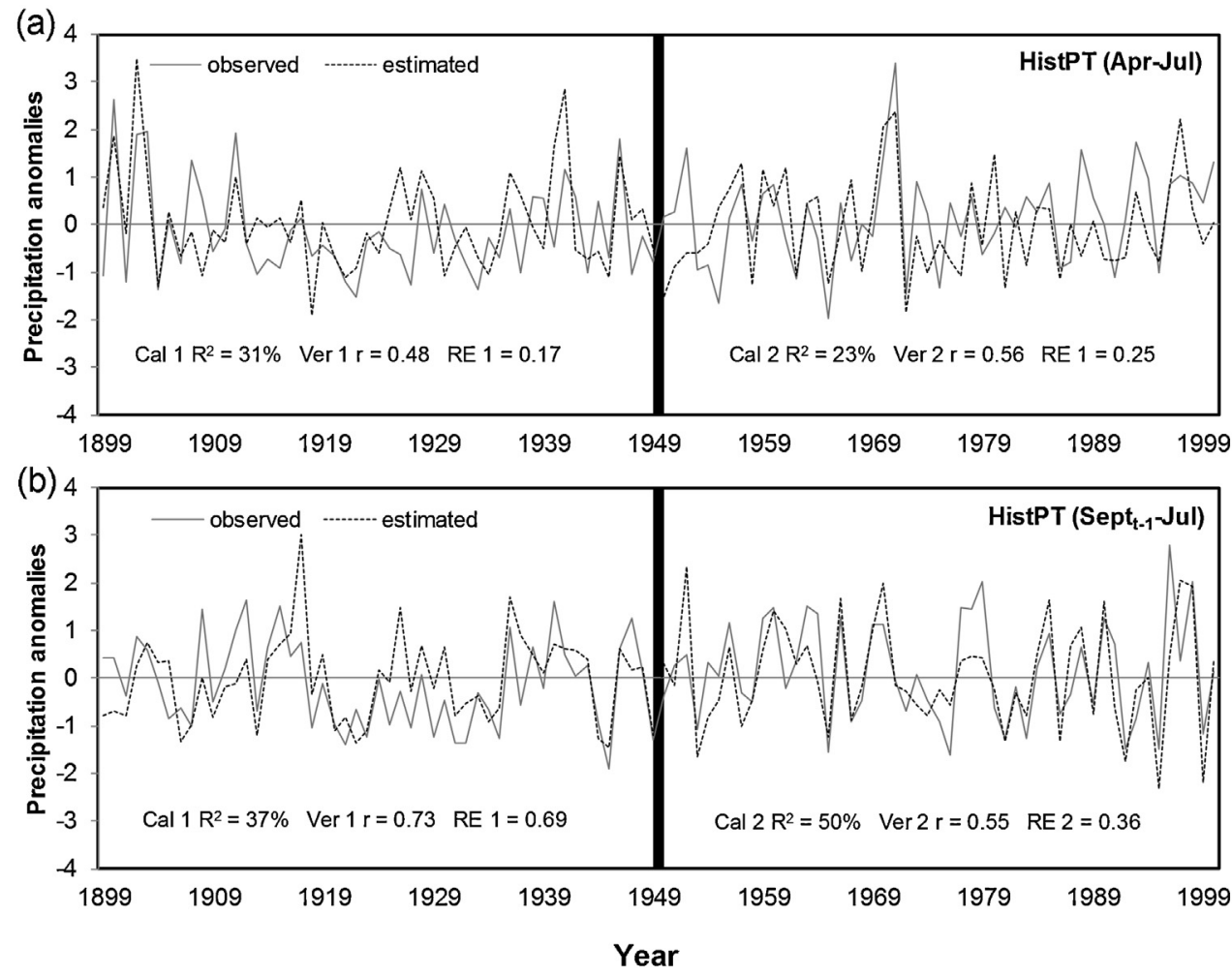

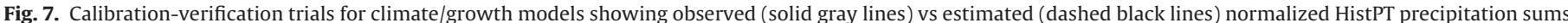

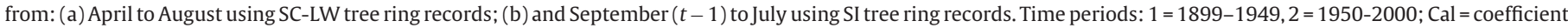

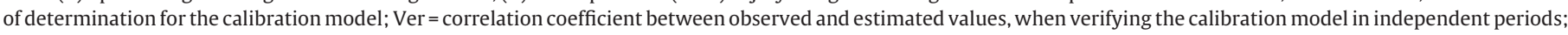
$\mathrm{RE}=$ reduction of error.

extend beyond the existing instrumental records, the crossdating potential and sensitivity to climate make older oak trees and subfossil material promising. Oak species are very important players of the Portuguese forest heritage with a long presence in the country and a high economical value in the past, e.g. for naval construction. Sub-aquatic sources of archeological wood material are common and could contribute to the extension of tree ring records.

\section{Conclusions}

The present study demonstrates that long-lived trees suitable for dendroclimatic reconstructions can indeed be found in Portugal and, in the case of $Q$. pyrenaica and $Q$. faginea, sampling can resort to cores; the longest tree-ring series presented in this study extends 173 years in time back to 1840. Q. ilex trees growing at the South interior (SI) show a very strong climatic signal; a ringwidth chronology explains more than $65 \%$ of the total variability in precipitation. This is even higher than for tree-rings from centralEuropean climates, which generally tend to show stronger signals than those of Mediterranean areas. Tree rings from Q. ilex and from Q. faginea trees, growing at the South coastal belt (SC-LW), show stable and high climate/growth relationships from 1920 onwards. Calibration models built for the period covered by the instrumental data are, therefore, reliable for the reconstruction of precipitation back to periods represented only by tree-ring records.

However, some shortcomings are still noteworthy:

- The strongest climatic signals were found for Q. ilex, which has to be sampled using whole stem disks, a destructive method, and taking advantage of authorized feeling's which limits the experimental design.
- The SC-LW chronology climatic signal strength, though in accordance with other studies for the Mediterranean and temporally stable, is weak for dendroclimatic reconstructions. It explains only $24 \%$ of the observed spring-summer precipitation.

- The tree ring records, although extending beyond the instrumental records for the region, do not provide additional information about the past. The historic precipitation series for Portugal from Camuffo et al. (2013) are longer than these chronologies and, as expected, show a better agreement with the regional precipitation.

Further research using older oak trees and subfossil material is needed to extend the tree-ring records in time. Nevertheless, the present study provides an important breakthrough in Iberian dendrochronology with promising results for forthcoming research on climate reconstruction in Portugal.

\section{Acknowledgements}

This study was carried out within the framework of the projects PTDC/AAC-CLI/103046/2008, PTDC/AAC-CLI/119078/2010, and PTDC/HIS-ARQ/117099/2010 supported by national funds from FCT - Portuguese Foundation for Science and Technology and PEst - OE/AGR/UI4033/2014. Filipe Campelo was supported by a postdoctoral research grant (SFRH/BPD/47822/2008) from FCT with funds from POPH (Portuguese Operational Human Potential Program) and QREN Portugal (Portuguese National Strategic Reference Framework). The first author acknowledges a postdoctoral grant (SFRH/BPD/44493/2008) and a grant under the FCT Investigator Programme (IF/00826/2012) both supported by FCT. We wish to thank Umut Sen, António Nogueira, and Eva Medina, for assistance in fieldwork; Alexandra Lauw for advice during laboratory work; Rui Rebelo and the Centre for Environmental 
Biology (FCUL) for permission to sample within their field station "Herdade da Ribeira Abaixo"; Luís Grilo and Parque Natural de São Mamede for sampling permission.

\section{References}

Abrantes, J., Campelo, F., García-González, I., Nabais, C., 2013. Environmental control of vessel traits in Quercus ilex under Mediterranean climate: relating xylem anatomy to function. Trees-Struct. Funct. 27, 655-662, http://dx.doi.org/10. 1007/s00468-012-0820-6

Andreu-Hayles, L., Planells, O., Gutiérrez, E., Muntan, E., Helle, G., Anchukaitis, K.J., Schleser, G.H., 2011. Long tree-ring chronologies reveal 20th century increases in water-use efficiency but no enhancement of tree growth at five Iberian pine forests. Glob. Change Biol. 17, 2095-2112, http://dx.doi.org/10.1111/j.13652486.2010.02373.x

Azevedo, O.V., 1997. A Floresta e o Domínio do Mar. Memórias, vol. XXVII. Academia de Marinha, Lisboa.

Barber, K.E., Maddy, D., Rose, N., Stevenson, A.C., Stoneman, R., Thompson, R., 2000. Replicated proxy-climate signals over the last $2000 \mathrm{yr}$ from two distant UK peat bogs: new evidence for regional palaeoclimate teleconnections. Quat. Sci. Rev. 19, 481-487, http://dx.doi.org/10.1016/S0277-3791(99)00102-X

Beniston, M., Stephenson, D.B., Christensen, O.B., Ferro, C.A.T., Frei, C., Goyette, S., Halsnaes, K., Holt, T., Jylha, K., Koffi, B., Palutikof, J., Scholl, R., Semmler, T., Woth, K., 2007. Future extreme events in European climate: an exploration of regional climate model projections. Clim. Change 81, 71-95, http://dx.doi.org/10.1007/ s10584-006-9226-z

Benito-Garzon, M., Sanchez-de-Dios, R., Sainz-Ollero, H., 2008. Effects of climate change on the distribution of Iberian tree species. Appl. Veg. Sci. 11, 169-178, http://dx.doi.org/10.3170/2008-7-18348

Blasing, T.J., Duvick, D.N., West, D.C., 1981. Dendroclimatic calibration and verification using regionally averaged and single station precipitation data. Tree-Ring Bull. 41, 37-43.

Briffa, K.R., Schweingruber, F.H., Jones, P.D., Osborn, T.J., Harris, I.C., Shiyatov, S.G., Vaganov, E.A., Grudd, H., 1998. Trees tell of past climates: but are they speaking less clearly today? Philos. Trans. R. Soc. Lond. Ser. B: Biol. Sci. 353, 65-73, http:// dx.doi.org/10.1098/rstb.1998.0191

Büntgen, U., Frank, D.C., Schmidhalter, M., Neuwirth, B., Seifert, M., Esper, J., 2006. Growth/climate response shift in a long subalpine spruce chronology. TreesStruct. Funct. 20, 99-110, http://dx.doi.org/10.1007/s00468-005-0017-3

Büntgen, U., Frank, D., Trouet, V., Esper, J., 2010. Diverse climate sensitivity of Mediterranean tree-ring width and density. Trees-Struct. Funct. 24, 261-273, http://dx.doi.org/10.1007/s00468-009-0396-y

Campelo, F., Gutiérrez, E., Ribas, M., Nabais, C., Freitas, H., 2007a. Relationships between climate and double rings in Quercus ilex from northeast Spain. Can. J. For. Res. 37, 1915-1923, http://dx.doi.org/10.1139/X07-050

Campelo, F., Nabais, C., Freitas, H., Gutiérrez, E., 2007b. Climatic significance of tree-ring width and intra-annual density fluctuations in Pinus pinea from a dry Mediterranean area in Portugal. Ann. For. Sci. 64, 229-238, http://dx.doi.org/10. 1051/forest:2006107

Campelo, F., Nabais, C., García-González, I., Cherubini, P., Gutiérrez, E., Freitas, H., 2009. Dendrochronology of Quercus ilex L. and its potential use for climate reconstruction in the Mediterranean region. Can. J. For. Res. 39, 2486-2493, http://dx. doi.org/10.1139/X09-163

Campelo, F., Nabais, C., Gutiérrez, E., Freitas, H., García-González, I., 2010. Vessel features of Quercus ilex L. growing under Mediterranean climate have a better climatic signal than tree-ring width. Trees-Struct. Funct. 24, 463-470, http://dx. doi.org/10.1007/s00468-010-0414-0

Campelo, F., García-González, I., Nabais, C., 2012. detrendeR - a graphical user interface to process and visualize tree-ring data using R. Dendrochronologia 30 , 57-60, http://dx.doi.org/10.1016/j.dendro.2011.01.010

Campelo, F., Vieira, J., Nabais, C., 2013. Tree-ring growth and intra-annual density fluctuations of Pinus pinaster responses to climate: does size matter? Trees 27, 763-772, http://dx.doi.org/10.1007/s00468-012-0831-3

Camuffo, D., Bertolin, C., Diodato, N., Cocheo, C., Barriendos, M., Dominguez-Castro, F., Garnier, E., Alcoforado, M.J., Nunes, M.F., 2013. Western Mediterranean precipitation over the last 300 years from instrumental observations. Clim. Change 117, 85-101, http://dx.doi.org/10.1007/s10584-012-0539-9

Candel-Perez, D., Linares, J.C., Vinegla, B., Lucas-Borja, M.E., 2012. Assessing climate-growth relationships under contrasting stands of co-occurring Iberian pines along an altitudinal gradient. For. Ecol. Manag. 274, 48-57, http://dx.doi. org/10.1016/j.foreco.2012.02.010

Carrer, M., Urbinati, C., 2006. Long-term change in the sensitivity of tree-ring growth to climate forcing in Larix decidua. New Phytol. 170, 861-871, http://dx.doi.org/ 10.1111/j.1469-8137.2006.01703.x

Cherubini, P., Gärtner, B.L., Tognetti, R., Bräker, O.U., Schoch, W., Innes, J.L., 2003. Identification, measurement and interpretation of tree rings in woody species from Mediterranean climates. Biol. Rev. 78, 119-148, http://dx.doi.org/10.1017/ S1464793102006000

Cook, E., Holmes, R., 1986. Users Manual for Program ARSTAN. Laboratory of TreeRing Research, University of Arizona, Tucson, USA.

Cook, E.R., Kairiukstis, L.A., 1990. Methods of Dendrochronology: Applications in the Environmental Sciences. Kluwer Academic Publishers, Dordrecht, pp. 394.
Corcuera, L., Camarero, J.J., Gil-Pelegrín, E., 2002. Functional groups in Quercus species derived from the analysis of pressure-volume curves. Trees-Struct. Funct. 16, 465-472, http://dx.doi.org/10.1007/s00468-002-0187-1

Corcuera, L., Camarero, J.J., Gil-Pelegrín, E., 2004. Effects of a severe drought on growth and wood anatomical properties of Quercus faginea. Iawa J. 25, 185-204, http://dx.doi.org/10.1163/22941932-90000360

Corcuera, L., Camarero, J.J., Siso, S., Gil-Pelegrín, E., 2006. Radial-growth and woodanatomical changes in overaged Quercus pyrenaica coppice stands: functional responses in a new Mediterranean landscape. Trees-Struct. Funct. 20, 91-98, http://dx.doi.org/10.1007/s00468-005-0016-4

Cotillas, M., Sabate, S., Gracia, C., Espelta, J.M., 2009. Growth response of mixed Mediterranean oak coppices to rainfall reduction: could selective thinning have any influence on it? For. Ecol. Manag. 258, 1677-1683, http://dx.doi.org/10. 1016/j.foreco.2009.07.033

D’Arrigo, R., Wilson, R., Liepert, B., Cherubini, P., 2008. On the 'Divergence Problem' in Northern Forests: a review of the tree-ring evidence and possible causes. Glob. Planet. Change 60, 289-305, http://dx.doi.org/10.1016/j.gloplacha.2007.03.004

Diffenbaugh, N.S., Giorgi, F., 2012. Climate change hotspots in the CMIP5 global climate model ensemble. Clim. Change 114, 813-822, http://dx.doi.org/10.1007/ s10584-012-0570-X

Dorado-Liñán, I., Büntgen, U., Gonzalez-Rouco, F., Zorita, E., Montavez, J.P., Gomez-Navarro, J.J., Brunet, M., Heinrich, I., Helle, G., Gutierrez, E., 2012a. Estimating 750 years of temperature variations and uncertainties in the Pyrenees by tree-ring reconstructions and climate simulations. Clim. Past 8 919-933.

Dorado-Liñán, I., Gutiérrez, E., Andreu-Hayles, L., Heinrich, I., Helle, G., 2012b. Potential to explain climate from tree rings in the south of the Iberian Peninsula. Clim. Res. 55, 119-134, http://dx.doi.org/10.3354/Cr01126

Esper, J., Frank, D., Büntgen, U., Verstege, A., Luterbacher, J., 2007. Long-term drought severity variations in Morocco. Geophys. Res. Lett. 34, L17702, http://dx.doi.org/ 10.1029/2007gl030844

Fritts, H.C., 1976. Tree Rings and Climate. Academic Press, London.

Gao, X., Giorgi, F., 2008. Increased aridity in the Mediterranean region under greenhouse gas forcing estimated from high resolution simulations with a regional climate model. Glob. Planet. Change 62, 195-209, http://dx.doi.org/10.1016/j. gloplacha.2008.02.002

Gea-Izquierdo, G., Cañellas, I., 2014. Local climate forces instability in long-term productivity of a Mediterranean oak along climatic gradients. Ecosystems 17 228-241, http://dx.doi.org/10.1007/s10021-013-9719-3

Gea-Izquierdo, G., Martín-Benito, D., Cherubini, P., Cañellas, I., 2009. Climate-growth variability in Quercus ilex L. west Iberian open woodlands of different stand density. Ann. For. Sci. 66, 802, http://dx.doi.org/10.1051/forest/2009080

Gea-Izquierdo, G., Cherubini, P., Cañellas, I., 2011. Tree-rings reflect the impact of climate change on Quercus ilex L. along a temperature gradient in Spain over the last 100 years. For. Ecol. Manag. 262, 1807-1816, http://dx.doi.org/10.1016/ j.foreco.2011.07.025

Genova, M., 2012. Extreme pointer years in tree-ring records of Central Spain as evidence of climatic events and the eruption of the Huaynaputina Volcano (Peru 1600 AD). Clim. Past 8, 751-764, http://dx.doi.org/10.5194/cp-8-751-2012

Giorgi, F., 2006. Climate change hot-spots. Geophys. Res. Lett. 33, L08707, http://dx. doi.org/10.1029/2006GL025734

González-González, B.D., Rozas, V., García-González, I., 2014. Earlywood vessels of the sub-Mediterranean oak Quercus pyrenaica have greater plasticity and sensitivity than those of the temperate $Q$. petraea at the Atlantic-Mediterranean boundary. Trees-Struct. Funct. 28, 237-252, http://dx.doi.org/10.1007/s00468013-0945-2

Granda, E., Rossatto, D., Camarero, J.J., Voltas, J., Valladares, F., 2014. Growth and carbon isotopes of Mediterranean trees reveal contrasting responses to increased carbon dioxide and drought. Oecologia 174,307-317, http://dx.doi.org/10.1007 s00442-013-2742-4

Hughes, M.K., 2002. Dendrochronology in climatology - the state of the art. Dendrochronologia 20, 95-116, http://dx.doi.org/10.1078/1125-7865-00011

ICNF, 2013. IFN6 - Áreas dos usos do solo e das espécies florestais de Portugal continental. Resultados preliminares [pdf]. Instituto de Conservação da Natureza e das Florestas, Lisboa, pp. 35.

IPCC, 2014a. In: Field, C.B., Barros, V.R., Dokken, D.J., Mach, K.J., Mastrandrea, M.D. Bilir, T.E., Chatterjee, M. Ebi, K.L. Estrada, Y.O., Genova, R.C., Girma, B., Kissel, E.S., Levy, A.N., MacCracken, S., Mastrandrea, P.R., White, L.L. (Eds.), Climate Change 2014: Impacts, Adaptation, and Vulnerability. Part A: Global and Sectoral Aspects. Contribution of Working Group II to the Fifth Assessment Report of the Intergovernmental Panel on Climate Change. Cambridge University Press, Cambridge, United Kingdom and New York, NY, USA, p. 1132

IPCC, 2014b. In: Barros, V.R., Field, C.B. Dokken, M.D, Mastrandrea, Mach, K.J Bilir, T.E., Chatterjee, M., Ebi, K.L., Estrada, Y.O., Genova, R.C., Girma, B., Kissel, E.S., Levy, A.N., MacCracken, S., Mastrandrea, P.R., White, L.L. (Eds.), Climate Change 2014: Impacts, Adaptation, and Vulnerability. Part B: Regional Aspects. Contribution of Working Group II to the Fifth Assessment Report of the Intergovernmental Panel on Climate Change. Cambridge University Press, Cambridge United Kingdom and New York, NY, USA, p. 688.

Kottek, M., Grieser, J., Beck, C., Rudolf, B., Rubel, F., 2006. World map of the Koppen-Geiger climate classification updated. Meteorologische Zeitschrift 15 , 259-263, http://dx.doi.org/10.1127/0941-2948/2006/0130

Leal, S., Nunes, E., Pereira, H., 2008. Cork oak (Quercus suber L.) wood growth and vessel characteristics variations in relation to climate and cork harvesting. Eur. J. For. Res. 127, 33-41, http://dx.doi.org/10.1007/s10342-007-0180-8 
Liñares, J.C., Tiscar, P.A., 2011. Buffered climate change effects in a Mediterranean pine species: range limit implications from a tree-ring study. Oecologia 167, 847-859, http://dx.doi.org/10.1007/s00442-011-2012-2

Nicault, A., Alleaume, S., Brewer, S., Carrer, M., Nola, P., Guiot, J., 2008. Mediterranean drought fluctuation during the last 500 years based on tree-ring data. Clim. Dyn. 31, 227-245, http://dx.doi.org/10.1007/s00382-007-0349-3

Nikulin, G., Kjellstrom, E., Hansson, U., Strandberg, G., Ullerstig, A., 2011. Evaluation and future projections of temperature, precipitation and wind extremes over Europe in an ensemble of regional climate simulations. Tellus Ser. a - Dyn. Meteorol. Oceanogr. 63, 41-55, http://dx.doi.org/10.1111/j.1600-0870.2010. 00466.x

Olano, J.M., Eugenio, M., García-Cervigón, A.I., Folch, M., Rozas, V., 2012. Quantitative tracheid anatomy reveals a complex environmental control of wood structure in continental Mediterranean climate. Int. J. Plant Sci. 173, 137-149, http://dx. doi.org/10.1086/663165

Pasho, E., Camarero, J.J., de Luis, M., Vicente-Serrano, S.M., 2011. Impacts of drough at different time scales on forest growth across a wide climatic gradient in north eastern Spain. Agric. For. Meteorol. 151, 1800-1811, http://dx.doi.org/10.1016 j.agrformet.2011.07.018

Roig, F.A., Barriopedro, D., Herrera, R.G., Dominguez, D.P., Monge, S., 2009. North Atlantic Oscillation signatures in Western Iberian tree-rings. Geografisk Annaler Ser. A - Phys. Geogr. 91A, 141-157, http://dx.doi.org/10.1111/j.1468 0459.2009.00360.x

Rozas, V., Lamas, S., García-González, I., 2009. Differential tree-growth responses to local and large-scale climatic variation in two Pinus and two Quercus species in northwest Spain. Ecoscience 16, 299-310, http://dx.doi.org/10.2980/16-3-3212

Sanchez-Salguero, R., Navarro-Cerrillo, R.M., Camarero, J.J., Fernandez-Concio, A. 2010. Drought-induced growth decline of Aleppo and maritime pine forests in south-eastern Spain. For. Syst. 19, 458-469.

Santos, J.A., Carneiro, M.F., Alcoforado, M.J., Leal, S., Luz, A.L., Camuffo, D., Zorita, E. 2015. Calibration and multi-source consistency analysis of reconstructed precipitation series in Portugal since the early 17th century. Holocene 25, 663-676, http://dx.doi.org/10.1177/0959683614566250

Sarris, D., Christodoulakis, D., Korner, C., 2011. Impact of recent climatic change on growth of low elevation eastern Mediterranean forest trees. Clim. Change 106, 203-223, http://dx.doi.org/10.1007/s10584-010-9901-y
Schweingruber, F.H., Bartholin, T., Schar, E., Briffa, K.R., 1988, Radiodensitometricdendroclimatological conifer chronologies from Lapland (Scandinavia) and the Alps (Switzerland). Boreas 17, 559-566.

Touchan, R., Xoplaki, E., Funkhouser, G., Luterbacher, J., Hughes, M.K., Erkan, N., Akkemik, U., Stephan, J., 2005. Reconstructions of spring/summer precipitation for the Eastern Mediterranean from tree-ring widths and its connection to largescale atmospheric circulation. Clim. Dyn. 25, 75-98, http://dx.doi.org/10.1007/ s00382-005-0016-5

Touchan, R., Anchukaitis, K.J., Meko, D.M., Sabir, M., Attalah, S., Aloui, A., 2011 Spatiotemporal drought variability in northwestern Africa over the last nine centuries. Clim. Dyn. 37, 237-252, http://dx.doi.org/10.1007/s00382-010-0804-

Trouet, V., Esper, J., Graham, N.E., Baker, A., Scourse, J.D., Frank, D.C., 2009. Persistent positive North Atlantic Oscillation mode dominated the medieval climate anomaly. Science 324, 78-80, http://dx.doi.org/10.1126/science.1166349

Vieira, J., Campelo, F., Nabais, C., 2010. Intra-annual density fluctuations of Pinus pinaster are a record of climatic changes in the western Mediterranean region. Can. J. For. Res. 40, 1567-1575, http://dx.doi.org/10.1139/X10-096

Wigley, T.M.L., Briffa, K.R., Jones, P.D., 1984. On the average value of correlated time-series, with applications in dendroclimatology and hydrometeorology. J. Clim. Appl. Meteorol. 23, 201-213, http://dx.doi.org/10.1175/15200450(1984)023<0201:Otavoc >2.0.Co:2

Wiles, G.C., D’Arrigo, R.D., Barclay, D., Wilson, R.S., Jarvis, S.K., Vargo, L., Frank, D. 2014. Surface air temperature variability reconstructed with tree rings for the Gulf of Alaska over the past 1200 years. Holocene 24, 198-208, http://dx.doi. org/10.1177/0959683613516815

Wilmking, M., Juday, G.P., Barber, V.A., Zald, H.S.J., 2004. Recent climate warming forces contrasting growth responses of white spruce at treeline in Alaska through temperature thresholds. Glob. Change Biol. 10, 1724-1736, http://dx. doi.org/10.1111/j.1365-2486.2004.00826.x

Wilson, R., Elling, W., 2004. Temporal instability in tree-growth/climate response in the Lower Bavarian Forest region: implications for dendroclimatic reconstruction. Trees-Struct. Funct. 18, 19-28, http://dx.doi.org/10.1007/s00468003-0273-z. 